REKOGNISI: Jurnal Pendidikan dan Kependidikan

ISSN 2527-5259 Vol.1 No.1 Desember 2016

\title{
DAKWAH TAREKAT PADA LEMBAGA PENDIDIKAN
}

\author{
Abrar M. Dawud Faza \\ FUSI Universitas lslam Negeri Sumatera Utara \\ Email:abrardawud@yahoo.com
}

\begin{abstract}
ABSTRAK
Dakwah tarekat di Indonesia awalnya terjadi melalui pendidikan informal, yang berlanjut hingga pendidikan formal. Pendidikan Islam secara informal dilaksanakan dengan menyesuaikan perasaan dan cara hidup orang-orang pada masa itu. Pendidikan informal disampaikan lewat oral atau dakwah lisan dan tingkah laku melalui interaksi langsung antara pemberi dan penerima. Seiring berjalannya waktu, pendidikan informal yang dienyam oleh masyarakat setempat membentuk komunitas muslim yang memiliki keinginan yang sama untuk mengamalkan ajaran Islam dalam keseharian hidup mereka, yang ditandai dengan adanya pembangunan masjid di daerah tersebut. Pendidikan formal diselenggarakan secara terlembaga. Dakwah tarekat melalui pendidikan formal dilaksanakan di masjid, langgar, pesantren, meunasah, rangakang, dayah, dan surau. Dakwah tarekat dalam lembaga pendidikan di Indonesia dilakukan oleh para guru dan kyai.
\end{abstract}

Kata kunci: dakwah tarekat, lembaga pendidikan 


\begin{abstract}
Preaching congregation in Indonesia initially occurs through informal approach, which continues to formal education. Islamic education informally implemented by adjusting the feelings and the way of life of people at that time. Informal education delivered by oral or oral propoganda and behaviour through direct interaction beetween the giver and the receiver. Over time, informal education through by local people formed the muslim community who have the same desire to practice the teacings of Islam in their daily lives, which is characterized by the construction of a mosque in the area. Formal education was held in institutionalized. Preaching congregation through formal education implemented in the mosque, langgar, boarding, meunasah, rangkang, dayah, and surau. In education institutions, preaching congregation in Indonesia carried out by teachers and clerics.
\end{abstract}

Key words: educational institutions, preaching congregation

\title{
PENDAHULUAN
}

Sebagai agama dunia, Islam telah menyebar tidak hanya di sekitar kawasan Arab atau Timur Tengah sebagai asal kelahirannya. Islam juga menyebar luas dan berkembang pesat sebagai proses islamisasi lebih jauh di kawasan lain, salah satunya di Asia Tenggara.

Proses islamisasi di Timur Tengah uniknya berbeda dengan proses islamisasi di Asia Tenggara. S dan M (2003: 1) menyatakan proses islamisasi di Timur Tengah terjadi lewat proses penaklukan, ekspansi (futuhat) atau pendudukan dengan menggunakan kekuatan militer melalui peperangan, sedangkan di Asia Tenggara penyebaran dan perkembangan Islam berlangsung secara damai (penetration pacifigure).

Proses islamisasi di nusantara terjadi melalui jalur perdagangan, sufistik, dakwah, perkawinan, seni-budaya, pendidikan dan sebagainya. (2003: 2) menyatakan hal tersebut menjadikan perkembangan Islam di nusantara berbeda dengan daerah asalnya di Timur Tengah, di mana penyerapan atau transformasi nilai-nilai Islam terhadap kehidupan masyarakat terjadi secara gradual (bertahap), damai, dinamis, toleran dan bahkan mendukung proses pencerahan intelektualisme yang tidak terlihat agama Hindu-Budha yang ada pada saat itu.

Tulisan ini secara khusus akan menyelidiki salah satu faktor islamisasi di Indonesia, yakni melalui proses dakwah tarekat (sufistik). Pada gilirannya diharapkan dapat membuktikan bahwa sejarah panjang penyebaran Islam di Indonesia memungkinkan terjadinya proses transmisi keilmuan secara langsung dengan adanya kontak personal dengan ulama-ulama Timur Tengah yang terpusat 
di Haramain, sehingga kembalinya ke tanah air mereka mendirikan lembaga pendidikan sekaligus melakukan penyiaran agama Islam dengan dakwah tarekat.

\section{DAKWAH TAREKAT DAN PENDIDIKAN ISLAM}

Dakwah tarekat yang dilakukan pada awal masuknya Islam di Indonesia diakui sebagai cikal bakal islamisasi. Sehingga tidak dapat dipungkiri bahwa proses Islamisasi terjadi disebabkan adanya kontak antara ulama-ulama Nusantara dengan ulama-ulama Haramain. Haramayn (dua tanah haram) yaitu Mekah dan Madinah merupakan pusat keislaman yang memiliki kedudukan istimewa dalam kehidupan umat Islam di mana saja berada. Haramain merupakan tempat Islam diturunkan kepada Nabi Muhammad SAW dan kiblat umat Islam.

Sekilas perlu dikemukakan bagaimana proses terjadinya kontak Nusantara dengan Haramain. Menurut Azra (1994: 31) paling tidak ada empat hal: (1) Islam dibawa langsung dari Arabia; (2) Islam diperkenalkan oleh para guru dan muballigh (juru dakwah) yang khusus menyebarkan agama Islam; (3) masuk Islamnya para penguasa (raja-raja) dan (4) mulai banyaknya penyiar Islam, baik juru dakwah maupun guru-guru agama secara khusus datang ke Indonesia pada abad ke-12 dan ke-13 M. Lebih lanjut lagi Azra (1994: 32) menyimpulkan bahwa Islam sudah masuk ke Nusantara pada abad-abad pertama Hijriyah yaitu abad ke-7 dan ke-8.

Berdasarkan penjelasan di atas diperoleh keterangan bahwa di antara banyak faktor terjadinya islamisasi di Indonesia, maka faktor utamanya adalah keberadaan para guru agama (ulama) yang tidak saja berprofesi sebagai juru dakwah (muballigh), tetapi juga menjadi penyiar Islam lewat pendidikan Islam (tarbiyah islamiyah). Azra (1994: 35) juga menyimpulkan bahwa pengenalan Islam di Indonesia dilakukan melalui guru-guru dengan karakteristik sufistik.

Kehadiran para guru sufi pengembara (muballigh) mendakwahkan Islam berpindah dari satu tempat ke tempat lain, mereka ini merambah berbagai tempat, termasuk daerah-daerah pedalaman yang tertutup. Azra (2006: 23) menyatakan mereka bisa beradaptasi dan menyiarkan Islam menurut tradisi setempat.

Keberadaan lembaga-lembaga pendidikan di tanah air diawali dengan tumbuh dan berkembangnya lembaga-lembaga pendidikan di dunia Islam, termasuk di Haramain. Sebelum munculnya madrasah, pendidikan Muslim sejak masa Nabi Muhammad telah berlangsung terutama di seputar masjid dan rumah guru. Menurut Azra (2006: 62) menyatakan pendidikan dilaksanakan dalam halaqah, majlis tadris dan kuttab. Sementara lembaga-lembaga pendidikan yang terkenal di dunia Islam pada zaman klasik adalah: kuttab, masjid dan madrasah. Daulay (2009: 95) membaginya kepada: maktab/kuttab, al-jami', majelis ilmu atau majelis adab, dan madrasah atau kuliah. 


\section{PERAN LEMBAGA PENDIDIKAN DALAM DAKWAH TAREKAT}

\section{Pendidikan Informal}

Penjelasan sebelumnya telah diperoleh keterangan bahwa islamisasi yang terjadi di tanah air tidak dapat dilepaskan dari kedudukan guru-guru maupun muballigh yang menyampaikan ajaran Islam di tengah-tengah masyarakat. Maksudnya, para penyiar agama Islam menggunakan pendidikan (pengajaran dalam makna yang luas) sebagai media islamisasi.

Muballigh itu sebagian mempunyai lembaga pendidikan dan sebagian lainnya tidak. Daulay (2009: 56) menyatakan bila dari perspektif esensi pendidikan, aktivitas yang dilakukan oleh para muballigh awal yang datang ke Indonesia baik sebagai muballigh semata (tidak punya lembaga pendidikan khusus) dan muballigh yang mendirikan lembaga pendidikan (madrasah dalam pengertian luas) adalah kegiatan yang terkait dengan pendidikan. Haidar (2009: 12) menyimpulkan bahwa pendidikan Islam di Indonesia telah berlangsung sejak masuknya Islam ke Indonesia dan dengan demikian pendidikan Islam telah memainkan perannya dalam proses islamisasi di Indonesia.

Hal ini cukup beralasan sebab ukuran (standar) apakah kegiatan muballigh itu tergolong kepada aktivitas pendidikan dapat ditimbang berdasarkan lima unsur pendidikan. Muhadjir (1987: 5) menyatakan kelima unsur pendidikan yang dimaksud antara lain: 1) adanya pendidik (pemberi ilmu); 2) adanya objek yang dididik atau peserta didik (penerima ilmu); 3) adanya tujuan baik (menyiarkan nilai-nilai); 4) caranya baik (tauladan, tabligh dan sebagainya) dan 5) konteks positif untuk menghindari konteks negatif (menjauhkan atau menghindarkan peserta didik dari sesuatu yang tidak baik menuju keadaan yang baik).

Kelima unsur tersebut menunjukkan bahwa transformasi sosial yang dilakukan oleh para muballigh termasuk proses pendidikan. Dapat disebut pula bahwa masa-masa awal pertumbuhan pendidikan Islam di Indonesia, pendidikan telah berlangsung secara informal. Di mana kontak-kontak person antara muballigh dan umat di lingkungannya tidak dimulai atau disusun berdasarkan struktur (kurikulum atau silabus) yang jelas dan tegas. Pergaulan sehari-hari di mana di dalamnya termuat berbagai unsur pendidikan, seperti tabligh (penyampaian pesanpesan agama) dan suri tauladan (contoh-contoh yang baik) ditampilkan oleh para muballigh menjadi nilai khusus dan menarik simpati masyarakat di lingkungannya hingga akhirnya masyarakat tersebut rela secara ikhlas masuk kepada agama Islam.

Bagaimana bijaksananya muballigh-muballigh dalam masa permulaan Islam di Jawa misalnya, dalam segala usahanya mereka menyesuaikan perasaan dan cara hidup orang-orang yang ada waktu itu. Ini merupakan strategi dakwah agar masyarakat dapat menerima pengajaran atau pendidikan Islam. Mulyati (2006: 10) memberikan contoh penyesuaian yang dimaksud yiatu bentuk masjid yang masih disesuaikan dengan rumah ibadah Hindu-Budha, cerita-cerita Islam 
yang masuk dalam tradisi kesenian wayang, gamelan dan sebagainya yang sengaja disesuaikan untuk menarik simpati masyarakat dan tidak menimbulkan kegoncangan sosial dengan nilai-nilai Islam yang baru mereka dengar dari para juru dakwah Islam (muballigh).

Kegiatan-kegiatan tersebut secara perlahan dan simultan membentuk komunitas Muslim yang memiliki visi dan misi yang sama terhadap pengamalan agama Islam dalam keseharian hidup mereka. Hal tersebut ditandai dengan di awali mendirikan masjid (rumah ibadah) hingga akhirnya mendirikan madrasah sebagai tempat khusus menuntut ilmu.

Pendidikan Islam pertama kali tumbuh dan berkembang dalam proses islamisasi adalah pendidikan dalam bentuk informal, yakni tidak memiliki tempat, waktu, materi, dan pedoman pengajaran yang khusus, namun disampaikan lewat oral (mulut ke mulut) atau dakwah bil lisan (dengan ucapan) dan bil arkan (dengan tubuh atau tingkah laku). Pendidikan Islam ini terjadi lewat kontak-kontak person antara pemberi dan penerima atau dapat disebut antara guru dan murid.

Kontak-kontak atau hubungan antar person itu tidak terprogram secara rigit dan ketat sehingga pendidikan belum melembaga sebagai suatu lembaga pendidikan tertentu. Daulay (2009: 13) menyatakan muballigh adalah orang yang paling berperan dalam hal tersebut.

Jelaslah bahwa sejak awal masuknya Islam ke Indonesia, pendidikan Islam merupakan kepentingan tertinggi bagi kaum muslimin. Tetapi hanya sedikit sekali yang dapat kita ketahui tentang perkembangan pendidikan Islam di masa lalu. Di Indonesia tidak dipungkiri terdapat hubungan intelektual antara tokoh-tokoh Indonesia dengan tokoh-tokoh Timur Tengah, khususnya sesuatu yang berhubungan dengan tradisi keagamaan yang sarat dengan misi dakwah dan pendidikan Islam.

Awal terjadinya proses pendidikan Islam di Indonesia dimulai dengan berbagai kontak yang dilakukan oleh para saudagar Gujarat, misalnya kontak jual beli, kontak perkawinan, kontak dakwah langsung baik secara individual maupun kolektif. Materi yang pertama sekali adalah kalimat syahadat kemudian dikembangkan pada penganjuran hablum minallah (ibadah mahdah) dan hablum minannas (ibadah sosial).

Setelah pendidikan informal itu berlangsung, muncullah pendidikan formal, yaitu pendidikan yang terencana, punya waktu dan tempat serta materi tertentu. Pendidikan formal tersebut dilaksanakan di Masjid dan Langgar, pesantren, meunasah, rangkang dan dayah, surau dan madrasah, dan sebagainya. 


\section{Pendidikan Formal}

\section{a. Masjid dan Langgar}

Sejak Nabi Muhammad SAW terang-terangan berdakwah, masjid telah berkembang menjadi pusat pendidikan Islam. Di mana pun kaum muslimin berada, mereka selalu menjadikan masjid sebagai tempat pertemuan, pusat pendidikan, aktivitas administrasi dan sosial-budaya. Dhofier (1994: 49) menyatakan hal tersebut telah berlangsung selama 14 abad.

Ditemukan sejak awal masuknya Islam di Indonesia dan bahkan hingga saat ini, banyak para ulama yang menjadikan masjid atau Langgar sebagai basis atau pusat pendidikan dan dakwah Islam. Para ulama dengan penuh pengabdian dan niat yang ikhlas mengajar murid-murid dan masyarakat tentang ajaran Islam di masjid. Mereka juga menyampaikan wejangan atau tausyiah agama untuk kehidupan sehari-hari umatnya.

Para kyai di Jawa biasanya mendirikan Langgar terlebih dahulu sebagai awal mereka mendirikan pesantren. Dengan adanya Langgar, masyarakat dan murid-muridnya dapat diterapkan kedisiplinan mendirikan kewajiban sholat lima kali sehari semalam, di samping sebagai tempatnya menyampaikan pengajaran Islam.

Langgar fungsinya sama dengan masjid namun bentuknya yang lebih kecil. Daulay (2009: 20) meenyatakan di Langgar dapat dilaksanakan sholat lima waktu namun tidak bisa melaksanakan sholat Jum'at. Masjid pada awal masuknya Islam didirikan di tengah-tengah ibukota kerajaan atau dekat dengan istana raja. Hal ini memungkinkan bagi raja atau sultan untuk berhubungan secara langsung dengan rakyatnya dan juga dalam rangka penguatan institusi kerajaan di tengah kehidupan masyarakat yang dikuasainya.

Di Masjid dan Langgar dilakukan pendidikan untuk anak-anak dan orang dewasa. Pendidikan untuk anak-anak berupa kegiatan pengajian baca-tulis alQuran, pengenalan iman, ibadah dan akhlak, dan latihan sholat. Daulay (2009: 21) menyatakan kegiatan bagi orang dewasa yaitu pengajian berupa penyampaianpenyampaian ajaran Islam oleh para muballigh (ustadz, guru, kyai, dsb) di bidang aqidah, ibadah dan akhlak.

Masjid atau Langgar merupakan institusi pendidikan yang pertama dibentuk dalam lingkungan masyarakat Muslim. Pada dasarnya masjid atau langgar mempunyai fungsi yang tidak terlepas dari kehidupan keluarga. Masjid dan Langgar sebagai lembaga pendidikan, berfungsi untuk penyempurna pendidikan dalam keluarga, agar selanjutnya anak mampu melaksanakan tugas-tugas hidup dalam masyarakat dan lingkungannya. Pada mulanya pendidikan di Langgar atau Masjid, dalam arti sederhana dapat dikatakan sebagai lembaga pendidikan formal, dan sekaligus sebagai lembaga pendidikan sosial. 


\section{b. Pesantren}

Pesantren sudah ada sejak dahulu kala. Oleh karena itu, sudut pandang sejarah diperlukan untuk membahas kapan pertama kalinya pesantren berdiri. Daulay (2009: 21) menyatakan dari sudut pandang historis atau segi sejarah, belum ditemukan data sejarah, kapan pertama sekali berdirinya pesantren, ada pendapat mengatakan bahwa pesantren telah tumbuh sejak awal masuknya Islam ke Indonesia, sementara yang lain berpendapat bahwa pesantren baru muncul pada masa Wali Songo dan Maulana Malik Ibrahim dipandang sebagai orang yang pertama mendirikan pesantren.

Pesantren sendiri menurut pengertian dasarnya adalah tempat belajar santri. Pondok adalah rumah atau tempat tinggal sederhana yang terbuat dari bambu atau kayu biasa. Di samping itu, kata pondok mungkin juga berasal dari bahasa Arab yaitu funduq yang berarti hotel atau asrama.

Pembangunan suatu pesantren didorong oleh kebutuhan masyarakat akan adanya lembaga pendidikan lanjutan. Namun demikian, faktor guru yang memenuhi persyaratan keilmuan yang diperlukan akan sangat menentukan bagi tumbuhnya suatu pesantren. Pada umumnya berdirinya suatu pesantren diawali dari pengakuan masyarakat akan keunggulan dan ketinggian ilmu seorang guru atau kyai. Adanya keinginan untuk menuntut dan memproleh ilmu dari guru tersebut, maka masyarakat sekitar, bahkan dari luar daerah datang kepadanya untuk belajar.

Kelangsungan hidup suatu pesantren amat tergantung kepada daya tarik tokoh sentral (guru/kyai) yang memimpin, meneruskan atau mewarisinya. Jika pewaris menguasai sepenuhnya baik pengetahuan keagamaan, wibawa, keterampilan mengajar dan kekayaan lainnya yang diperlukan, maka umur pesantren tersebut akan lama bertahan. Sebaliknya pesantren akan menjadi mundur dan hilang, jika pewaris atau keturunan kyai yang mewarisinya tidak memenuhi persyaratan. Jadi seorang figur pesantren memang sangat menentukan dan benar-benar diperlukan.

Apabila ditelusuri sejarah pendidikan di Jawa, sebelum datangnya agama Islam telah ada lembaga pendidikan Jawa kuno yang praktik kependidikannya sama dengan pesantren. Lembaga pendidikan jawa kuno itu bernama "Pawiyatan", di lembaga tersebut tinggal Ki Ajar dengan Cantrik. Daulay (2009: 21) menyatakan Ki Ajar adalah orang yang mengajar dan Cantrik adalah orang yang belajar mengajar.

Dengan menganalogikan pendidikan pawiyatan ini dengan pesantren, sebetulnya tidak terlalu sulit untuk menetapkan bahwa pesantren itu telah tumbuh sejak awal perkembangan Islam di Indonesia khususnya di Jawa. Sebab model pendidikan pesantren itu telah ada sebelum Islam masuk yaitu pawiyatan. Dengan masuknya Islam, maka sekaligus diperlukan sarana pendidikan, tentu saja model 
pawiyatan ini dijadikan acuan dengan mengubah sistem yang ada ke sistem pendidikan Islam.

Inti dari pesantren itu adalah pendidikan ilmu agama, dan sikap beragama. Pada tingkat dasar, anak didik baru diperkenalkan tentang dasar agama dan alQur'an al-karim. Setelah berlangsung beberapa lama dan anak didik telah memiliki kecerdasan tertentu maka mulailah diajarkan kitab-kitab klasik. Kitab-kitab klasik ini juga di klasifikasikan kepada tingkat dasar, menengah dan tinggi. Mahmud Yunus (dalam Daulay, 2009: 22) membagi pesantren menjadi empat tingkatan, yaitu: (1) tingkat dasar; (2) menengah; (3) tinggi dan (4) takhassus.

Pasca datangnya penjajah Belanda, peranan pesantren sebagai lembaga pendidikan islam semakin kokoh. Pesantren merupakan lembaga pendi-dikan Islam yang reaksional terhadap penjajah. Karena itu, di zaman Belanda sangat kontras sekali perbedaan pendidikan di pesantren dengan pendidikan sekolahsekolah umum. Pesantren semata-mata mengajarkan ilmu-ilmu agama. Sistem pendidikan pesantren baik metode, sarana fasilitas serta yang lainnya masih bersifat tradisional. Daulay (2009: 22) menyatakan administrasi pendidikan pesantren belum seperti sekolah umum yang dikelola oleh pemerintah kolonial Belanda, non klasikal, metodenya sorogan, wetonan hapalan.

Administrasi pendidikan pesantren belum sebaik sekolah umum, namun pendidikan pesantren tidak kalah baiknya dengan sekolah umum. Menurut Dhofier (1994: 44) ada lima elemen pokok sebuah pesantren: pondok (tempat pendidikan dan asrama), masjid, pengajaran kitab-kitab klasik, santri, dan kyai.

Selanjutnya, pesantren mengalami dinamika, kemampuan dan kesediaan pesantren untuk mengadopsi nilai-nilai baru akibat modernisasi, menjadikan pesantren berkembang dari yang tradisional ke modern. Daulay (2009: 22), hingga saat sekarang pesantren tersebut di bagi menjadi dua secara garis besar yaitu pesantren salafi adalah pesantren yang masih terkait dengan sistem dan pola yang lama, dan pesantren khalafi adalah pesantren yang telah menerima unsur-unsur pembaharuan atau modern.

\section{c. Meunasah, Rangkang dan Dayah}

Menurut pengertian istilah atau etimologi, meunasah berasal dari perkataan madrasah, tempat belajar atau sekolah. Bagi masyarakat Aceh meunasah tidak hanya semata-mata tempat belajar, bagi mereka meunasah memiliki multi-fungsi. Daulay (2009: 23) menyatakan meunasah juga berfungsi tempat ibadah, tempat pertemuan, musyawarah, pusat informasi, tempat tidur, dan tempat menginap bagi musyafir, tempat perayaan kenduri massal dalam kampung, seperti maulid Nabi SAW, nuzulul quran, dan isra' mi'raj dan juga sebagai tempat pejabat-pejabat gampong (kampung) untuk memutuskan dan memecahkan masalah-masalah sosial yang dihadapi masyarakat. 
Menurut Qanun Meukuta Alam, dalam tiap-tiap kampung harus ada satu meunasah. Masjid berfungsi sebagai tempat berbagai kegiatan umat, termasuk di dalamnya kegiatan pendidikan. Karena murid perlu mondok dan tinggal, maka perlu di bangun tempat tinggal mereka di sekitar masjid, tempat tinggal murid di sekitar inilah yang disebut dengan rangkang. Pendidikan di rangkang ini terpusat kepada pendidikan agama, di sini telah diajarkan kitab-kitab yang berbahasa Arab, tingkat pendidikan ini jika dibandingkan dengan sekolah saat sekarang adalah SLTP. Sistem pendidikan di rangkang ini sama dengan pendidikan di pesantren. Di rangkang juga ada yang namanya tengku rangkang, yang bertugas untuk menjadi guru bantu yang membimbing sisiwa yang tinggal di rangkang.

Dalam paradigma pendidikan, meunasah adalah lembaga pendidikan awal bagi anak-anak yang dapat disamakan dengan tingkatan sekolah dasar. Hasjmy (1983: 192) menyatakan di meunasah para murid di ajari menulis, membaca huruf Arab, ilmu agama, dan akhlaq. Meunasah dipimpin oleh seorang tengku, yang di Aceh besar disebut tengku meunasah. Tengku meunasah bertugas untuk membina agama di suatu tempet-tempat tertentu. Adapun rangkang adalah tempat tinggal murid, yang dibangun di sekitar masjid.

Lembaga pendidikan berikutnya yang popular di Aceh adalah dayah. Dayah berasal dari bahasa Arab, zawiyah. Kata zawiyah pada mulanya merujuk kepada sudut dari satu bangunan, dan sering dikaitkan dengan masjid. Di sudut masjid itu terdapat proses pendidikan antara si pendidik dengan si terdidik. Selanjutnya zawiyah dikaitkan dengan tarekat-tarekat sufi, di mana seorang syeikh atau mursyid melakukan kegitan pendidikan kaum sufi. Dengan demikian, kata dayah yang berasal dari kata zawiyah di samping memiliki hubungan kebahasaan yakni berubahnya kata zawiyah menjadi dayah menurut dialek Aceh, juga mempunyai hubungan fungsional, yakni sama-sama merujuk kepada tempat pendidikan.

Hasjmy menjelaskan tentang dayah adalah sebuah lembaga pendidikan yang mengajarkan mata pelajaran agama yang bersumber dari bahasa Arab, misalnya fiqih, bahasa Arab, tauhid tasawuf dan lain sebagainya. Tingkat pendidikan ini setara dengan SLTA. Pada Abad ke-18, surau dan dayah sudah mapan eksistensinya. Melalui lembaga-lembaga tersebut Islam telah mengakar kuat di Nusantara. Akan tetapi, keberadaan lembaga-lembaga ini mulai terancam bahaya kolonialisme yang menawarkan westernisasi, modernisasi, sekaligus kolonialisme sehingga ditantang kemampuannya untuk dapat menyesuaikan diri dengan tuntutan zaman. Menurut Hasjmy (1983: 195) besarnya tantangan lembaga pendidikan Islam pada masa itu telah mampu menghapuskan beberapa lembaga pendidikan tradisional dari pentas sejarah.

Berdasarkan uraian di atas, diketahui bahwa meunasah, rangkang dan dayah, maupun zawiyah, dalam prakteknya adalah sama dengan pesantren yang ada di tanah Jawa. Dengan kata lain, keempat nama tersebut adalah nama tempat belajar menuntut ilmu agama. 


\section{d. Surau}

Dalam Kamus Besar Bahasa Indonesia (2001: 1109), surau artinya tempat umat Islam melakukan ibadah. Pengertian ini apabila dirinci mempunyai arti bahwa surau berarti suatu tempat bangunan kecil untuk tempat shalat, tempat belajar mengaji anak-anak, tempat wirid bagi orang dewasa, sama halnya dengan masjid ataupun langgar.

Dobbin (dalam Daulay, 2009: 26) menyebutkan bahwa surau adalah rumah yang didiami para pemuda setelah akil balligh, terpisah dari rumah keluarganya yang menjadi tempat tinggal wanita dan anak-anak. Daulay (2009: 26) menyatakan perkataan surau menyebar luas di Indonesia dan Malaysia, yang dalam kehidupan keseharian adalah suatu bangunan kecil yang penggunaaan utamanya untuk shalat berjamaah bagi masyarakat sekitar.

Di Sumatera Barat pengertian surau tidak hanya berfungsi kepada beberapa fungsi yang disebutkan diatas,tetapi lebih luas dari itu lagi. Surau bagi masyarakat Minangkabau tidak hanya mempunyai fungsi pendidikan dan ibadah, tetapi lainnya juga mempunyai fungsi budaya.

Surau sebagai lembaga sosial budaya, berfungsi sebagai tempat pertemuan para pemuda dalam upaya mensosialisasikan diri mereka. Selain dari itu surau juga berfungsi sebagai tempat persinggahan dan peristirahatan para musafir yang sedang menempuh perjalanan. Dengan demikian surau mempunyai multifungsi.

Di dalam referensi lain dijelaskan pula oleh Azra bahwa surau juga menjadi tempat persinggahan bagi musafir dan sebagainya yang sedang melalui suatu desa. Dengan masuknya Islam, surau juga mengalami proses islamisasi. Azra (1994: 35) menyatakan selain fungsi surau sebagai tempat penginapan anak-anak bujang, tetapi fungsinya seperti fungsi masjid, yaitu sebagai tempat belajar membaca alQur'an dan dasar-dasar agama dan tempat ibadah.

\section{SIMPULAN}

Terjadinya proses dakwah tarekat di Indonesia salah satunya dipengaruhi oleh faktor pendidikan yang dilakukan secara informal maupun formal. Pendidikan secara informal diselenggarakan melalui aktivitas pendakwah tarekat yang berdakwah mengajarkan ajaran Islam. Ditandai dengan tidak adanya waktu, tempat, dan susunan materi yang khusus.

Pendidikan secara formal dilakukan oleh para guru, kyai dan sebagainya secara terlembaga, baik melalui masjid, surau, pesantren, dan sebagainya. Di dalamnya sudah disusun sedemikian rupa bentuk-bentuk pendidikan yang terencana dan terstruktur, baik dari segi tempat, waktu maupun materinya.

Melalui pendidikan Islam informal dan formal inilah dakwah tarekat dapat menyebar dan berkembang di tengah-tengah masyarakat Indonesia hingga saat 
REKOGNISI Vol.1 No.1 Desember 2016: 14-25

sekarang ini dan ini pula yang membedakannya dengan metode masuknya Islam di daerah lainnya yang dilakukan melalui penaklukan atau invasi (futuhat). Adapun di Indonesia dan Asia Tenggara, Islam masuk melalui jalan damai lewat berbagai cara seperti dakwah tarekat yang sudah dijelaskan sebelumnya. 
Dakwah Tarekat Pada Lembaga Pendidikan - Abrar M. Dawud Faza

\section{DAFTAR PUSTAKA}

Azra, A. 1994. Jaringan Ulama: Timur Tengah dan Kepulauan Nusantara Abad XVII-XVIII. Jakarta: Mizan

.2006. Renaisans Islam Asia Tenggara: Sejarah Wacana dan Kekuasaan. Jakarta: Rosda Karya.

Daulay, H. P. 2009. Dinamika Pendidikan Islam di Asia Tenggara. Jakarta: Rineka Cipta.

Dhofier, Z. 1994. Tradisi Pesantren: Studi tentang Pandangan Hidup Kyai. Jakarta: LP3ES.

Hasjmy, A. 1983. Kebudayaan Aceh dalam Sejarah. Jakarta: Beuna. , 2009 Sejarah Pertumbuhan dan Pembaruan Pendidikan Islam di Indonesia. Jakarta: Kencana.

Muhadjir, Noeng. 1987. Ilmu Pendidikan dan Perubahan Sosial. Jakarta: Rake Sarasin.

Mulyati, Sri. 2006. Tasawuf Nusantara: Rangkaian Mutiara Sufi Terkemuka. Jakarta: Kencana.

S, Mastuki H. dan M. Ishom el-Saha (ed.). 2003. Intelektualisme Pesantren: Potret Tokoh dan Cakrawala Pemikiran di Era Pertumbuhan Pesantren. Jakarta: Diva Pustaka.

Tim Penyusun. 2001. Kamus Besar Bahasa Indonesia. Jakarta: Balai Pustaka. 